\title{
Notes
}

\section{Original Issue Discount and the "LTV Risk" Reconsidered}

\author{
Craig Nemiroff
}

\section{INTRODUCTION}

In the 1980s, corporate America increased its indebtedness at a fantastic rate, ballooning the corporate debt burden from $\$ 829$ billion in 1980 to $\$ 2.1$ trillion in 1990. ${ }^{1}$ Companies that had financed their debt through the use of high-yield "junk bonds" eventually felt the weight of this mountain of new debt such that, by 1991 , nearly $15 \%$ of all junk-bond companies were in default and many others were in serious financial distress. ${ }^{2}$ As a result, companies increasingly tried to restructure their obligations in out-of-court workouts rather than face costly and time-consuming formal bankruptcy proceedings. ${ }^{3}$ One popular form of out-of-court workout that emerged was the debt-for-debt exchange offer, in which a company would offer new obligations with more forgiving payment terms in exchange for more burdensome existing obligations. ${ }^{4}$ If enough bondholders accepted the offer and tendered their bonds, the company could escape bankruptcy's costs and delays, and thereby distribute a higher payout to its creditors. These out-of-court workouts have generally been heralded as an efficient and cost-saving way for troubled companies to restructure their debts. ${ }^{5}$

1. Thomas McCarroll, Carry That Weight, TIME, Nov. 19, 1990, at 79, 79.

2. Edmund Faltermayer, The Deal Decade: Verdict on the '80s, FORTUNE, Aug. 26, 1991, at 58, 60; see also John J. Curran, Hard Lessons from the Debt Decade, FoRTuNE, June 18, 1990, at 76.

3. See, e.g., Allen L. Weingarten, Consensual Non-Bankruptcy Restructuring of Public Debt Securities, 23 REV. SEC. \& COMMODITIES REG. 159, 159 (1990) (noting "a greater emphasis on developing effective and cost-efficien[t] ways of restructuring troubled companies").

4. See Marc S. Kirschner et al., Prepackaged Bankruptcy Plans: The Deleveraging Tool of the '90s in the Wake of OID and Tax Concerns, 21 SETON HALL L. REv. 643, 645 (1991) (writing that "[f]or publicly traded debt... such workouts have most commonly taken the form of consensual exchange offers .... [in which] creditors swap existing debt instruments for substitute debt instruments").

5. See Stuart C. Gilson, Managing Default: Some Evidence on How Firms Choose Between Workouts and Chapter JI, J. APPLIED CORP. FIN., Summer 1991, at 62 (detailing inefficiencies of bankruptcy); $c f$. 
On January 11, 1990, Judge Burton Lifland of the United States Bankruptcy Court for the Southern District of New York issued an opinion in In re Chateaugay Corp. ${ }^{6}$ which critics charged created a significant disincentive against use of the debt-for-debt exchange offer in prebankruptcy workouts. Judge Lifland ruled that bondholders who participated in the LTV Corporation's prebankruptcy debt-exchange offer held claims equal only to the fair market value of the old debt that was exchanged, rather than the face amount of the new debt. ${ }^{7}$ Critics of the ruling argued that it would severely discourage creditors from participating in an exchange offer because they would be reluctant to have their bankruptcy claims reduced. ${ }^{8} \mathrm{~A}$ new term, "LTV risk," was coined to describe the fear creditors supposedly had of participating in exchange offers after the Chateaugay decision. ${ }^{9}$ Critics argued that this discouragement to creditors ran counter to the Bankruptcy Code's policy of encouraging out-of-court workouts. ${ }^{10}$

In 1992, after the district court affirmed the bankruptcy court's decision, the Second Circuit overruled it. ${ }^{11}$ Specifically, the court held that, for the purpose of calculating claims, no reduction in the amount of the claim should occur when debt of equal face value is exchanged. The court reasoned that the Bankruptcy Code does not place such an obstacle in the way of out-of-court restructurings. ${ }^{12}$ The Fifth Circuit, using similar logic, has reached the same conclusion. ${ }^{13}$

This Note argues that critics of the bankruptcy court decision in Chateaugay, and the courts of appeals who were influenced by these critics, ignored the economic substance of debt-for-debt exchange offers and created a claims-valuation regime directly contrary to the Bankruptcy Code. Whereas the Bankruptcy Code mandates that the face value of a bond shall not affect

Julian R. Franks \& Walter N. Torous, An Empirical Investigation of U.S. Firms in Reorganization, $44 \mathrm{~J}$. FiN. 747 (1991) (examining effects of bankruptcy on operational efficiency); Roger H. Gordon \& Burton G. Malkiel, Corporation Finance, in How TAXES AFFECT ECONOMIC BEHAVIOR 131, 163-72 (Henry Aaron \& Joseph Pechman eds., 1981) (enumerating sources of bankruptcy costs and estimating their magnitude). But cf. Robert A. Haugen \& Lemma W. Senbet, The Insignificance of Bankruptcy Costs to the Theory of Optimal Capital Structure, 33 J. FiN. 383 (1978) (arguing that bankruptcy costs have been overestimated).

6. In re Chateaugay Corp., 109 B.R. 51 (Bankr. S.D.N.Y. 1990), aff'd, 130 B.R. 403 (S.D.N.Y. 1991), aff'd in part and rev'd in part, 961 F.2d 378 (2d Cir. 1992).

7. Id. at 58 .

8. See, e.g., Weingarten, supra note 3 , at 163.

9. See, e.g., John C. Coffee, Jr. \& William A. Klein, Bondholder Coercion: The Problem of Constrained Choice in Debt Tender Offers and Recapitalizations, 58 U. CHI. L. REV. 1207, 1248-49 (1991); Richard L. Epling, Exchange Offers, Defaults, and Insolvency: A Short Primer, 8 BANKR. DEv. J. 15, 44 (1991).

10. See Chad C. Coombs, Original Issue Discount in Debt-for-Debt and Debt-for-Stock Exchanges, 65 AM. BANKR. L.J. 649 (1991); Robin E. Phelan \& Stacey Jernigan, The "LTV Risk": Bankruptcy Court Disallows "OLD" [sic] Created in Exchange Offer, in REAL ESTATE LAW \& PRACTICE COURSE HANDBOOK SERIES 1991, at 51, 62 (PLI Real Est. L. \& Practice Course Handbook Series No. 366, 1991).

11. Chateaugay, 961 F.2d 378 (2d Cir. 1992).

12. Id. at 383 .

13. Texas Commerce Bank v. Licht (In re Pengo Indus.), 962 F.2d 543 (5th Cir. 1992). 
the bankruptcy claim of a debt instrument, ${ }^{14}$ the Chateaugay reversal necessarily implies that the face amount of a debt instrument issued in the context of an exchange offer determines the bankruptcy claim associated with the new instrument. The courts of appeals disregarded the plain language of the Code in an attempt to encourage successful out-of-court workouts. This Note argues, however, that the reversal of Chateaugay was unnecessary for out-of-court workouts to remain a viable alternative to bankruptcy.

This Note first discusses the concept of original issue discount and how it has typically been interpreted in the bankruptcy setting. It then offers an explanation of Judge Lifland's analysis in Chateaugay and examines the analysis the appellate courts used in reaching contrary opinions. Next, the Note evaluates the two approaches to original issue discount in exchange offers and concludes that the bankruptcy court decision was improperly overruled. This Note argues that the appellate courts misinterpreted the economic underpinnings of a debt-exchange offer and fashioned a rule that creates enormous confusion and that may yield highly inequitable results if carried to its logical conclusion. Finally, the Note proposes that the promotion of out-ofcourt workouts-the sole reason for the Second Circuit's reversal-can be successfully accomplished through exchange offers in which the newly offered debt is senior to the old debt and this subordination is enforced in bankruptcy. The biggest threat to a successful exchange offer is a lack of creditor participation. This Note argues that creditors would be willing to participate in exchange offers that reduce their claims in bankruptcy if they could be reasonably assured that their bankruptcy recovery would be greater than the recovery of holdouts.

\section{ORIGINAL Issue Discount AND ITS LEgAL SignificANCE}

The intrinsic economic value of a bond is equal to the present value of the coupon payments plus the present value of the principal payment at maturity, all discounted at the market rate of return that corresponds to the risk characteristics of the security. When the market rate of return is more than the stated coupon rate, the market will discount the price of the bond, and the bond will trade for less than its face value. Such a bond is said to be selling at a "discount" from face value. The amount by which the face value exceeds the actual issuing price is called "original issue discount" (OID). ${ }^{15}$ Original issue discount is therefore nothing more than a market adjustment to reflect the

14. 11 U.S.C. § 502(b)(2) (1994).

15. See JaMes C. VAN HoRne \& John M. Wachowicz, JR., Fundamentals of Financial MANAGEMENT 74-94 (8th ed. 1992) (discussing valuation of long-term securities); Kirschner et al., supra note 4, at 649-50; cf. American Smelting \& Ref. Co. v. United States, 130 F.2d 883, 885 (3d Cir. 1942) ("Ordinarily, bonds are issued at a discount because the promised rate of interest is, due to the condition of the prevailing market, too low to sell them at par."). 
difference between the face value of a bond and its issuing price. As such, the discount represents the additional interest that accumulates over the life of the bond in excess of the interest paid out as coupon payments. ${ }^{16}$ Bankruptcy Code $\S 502$ (b) explicitly prohibits asserting a claim for such unmatured interest. ${ }^{17}$ For example, suppose Company $A$ issued bonds with a face amount (amount due at maturity) of $\$ 1000$ for an issue price of $\$ 700$. Such bonds have $\$ 300$ of original issue discount.

In bankruptcy, interest stops accruing on the date the petition for relief is filed. To the extent that on a given date interest has not yet accrued, it is classified for bankruptcy purposes as "unmatured." The legislative history of $\S 502$ (b) recognizes that the face amount of a bond is an inappropriate measure for valuating the claim of a creditor. Congress believed that the more appropriate measure was the sale price of the bond, i.e., the dollar amount loaned to the debtor, plus any interest that has accrued since the date of issue. $^{18}$ Thus, bonds issued at a discount contain "unmatured" interest to the extent that the face value exceeds the issue price; this unmatured interest is amortized over the life of the bond such that at maturity the market value of the bond eventually "catches up" to the face value. Courts have consistently held that unamortized original issue discount is unmatured interest and therefore is not an allowable claim. ${ }^{19}$ If Company $A$ in the above example

16. In Chateaugay, 109 B.R. at 55, Judge Lifland accurately explained:

If the proceeds from a particular issue are less than the face amount of the debentures, the "market" is telling the issuer that the stated rate of interest is too low, and the differential between consideration paid for the debenture and the amount received by the purchaser at maturity is intended to compensate the purchaser for buying a debenture with a stated interest rate below market levels.

17. Section 502(b)(2) of the Code states that the bankruptcy court is to allow a creditor's claim "except to the extent that . . . such claim is for unmatured interest." 11 U.S.C. $\$ 502(b)(2)$ (1994). Because interest is compensation for the use of money for a period of time, the Code will not allow a claim for the use of money over a period of time that has yet to come.

18. See Chateaugay, 109 B.R. at 54-55. The legislative history of $\$ 502(b)(2)$ reads:

Paragraph (2) requires disallowance to the extent that the claim is for unmatured interest as of the date of the petition. Whether interest is matured or unmatured on the date of bankruptcy is to be determined without reference to any ipso facto or bankruptcy clause in the agreement creating the claim. Interest disallowed under this paragraph includes postpetition interest that is not yet due and payable, and any portion of prepaid interest that represents an original discounting of the claim, yet that would not have been earned on the date of bankruptcy. For example, a claim on a $\$ 1000$ note issued the day before bankruptcy would only be allowed to the extent of the cash actually advanced. If the original discount was 10 percent so that the cash advanced was only $\$ 900$, then notwithstanding the face amount of the note, only $\$ 900$ would be allowed. If $\$ 900$ was advanced under the note some time before bankruptcy, the interest component of the note would have to be prorated and disallowed to the extent it was for interest after the commencement of the case.

H.R. REP. No. 595, 95th Cong., 1st Sess. 352-53 (1977), reprinted in 1978 U.S.C.C.A.N. 5963, 6308-09; S. REP. No. 989, 95th Cong., 2d Sess. 62 (1978), reprinted in 1978 U.S.C.C.A.N. 5787, 5848.

19. See In re Public Serv. Co., I14 B.R. 800, 803 (Bankr. D.N.H. 1990) ('The word 'interest' in the statute is clearly sufficient to encompass the OID variation in the method of providing for and collecting what in economic fact is interest to be paid to compensate for the delay and risk involved in the ultimate repayment of monies loaned."); In re Allegheny Int'l, Inc., 100 B.R. 247, 250 (Bankr. W.D. Pa. 1989) ("The facts of the instant case fit squarely within the example contained in the legislative history. The 
were to declare bankruptcy immediately after issuance of the securities, $\S 502$ (b) would only permit holders of the securities a claim of $\$ 700$ in bankruptcy. Section 502(b) would not allow a claim for the $\$ 300$ of original issue discount. Commentators generally agree that this reduction in claim is the appropriate and equitable treatment of purchasers of bonds issued at a discount. ${ }^{20}$ Such a policy makes perfect sense, for there is no reason that the Bankruptcy Code should favor those creditors who purchase discount bonds over those who purchase bonds at par or at a premium. The principle of equitable distribution of claims to creditors includes the notion that value received for a bond is the fairest measure of what is owed and, hence, the proper measure of the creditor's claim.

Not all new debt instruments are issued for cash, however. In a debt-fordebt exchange offer, bondholders surrender old debt in exchange for new debt of the issuing corporation. ${ }^{21}$ Prior to the Chateaugay decision, no court had ruled whether original issue discount could occur for claims-valuation purposes in a debt-for-debt exchange offer in which the new debt has a face value in excess of the market value of the surrendered instrument. From a purely economic perspective, such transactions do generate OID because the face amount of the new bonds exceeds what the bonds are worth when issued. However, original issue discount is also a legal construct, and courts are empowered to refuse to recognize OM, even when it may exist economically, if such recognition would otherwise violate bankruptcy policy. If bankruptcy courts are to hold that an exchange offer generates original issue discount, tendering creditors will have claims in bankruptcy equal only to the market value of the old securities. Thus, recognition of OID in a debt-for-debt exchange offer has the potential to make tendering creditors worse off than those who hold out if the debtor later files for bankruptcy.

There is, therefore, the potential for conflict between the competing concerns of accurately valuing the claims of creditors subsequent to an exchange offer and ensuring that out-of-court workouts are not unduly discouraged by such a valuation regime. When presented with this dilemma, Judge Lifland stressed the importance of economic substance and held that an

legislative history is clear; original issue discount is unmatured interest which is disallowed under 11 U.S.C. $\S 502(\mathrm{~b})(2) . ")$. Judge Lifiand, in his Chateaugay decision, stated:

Unmatured interest is without question not an allowed claim under $\S 502(b)(2)$ of the Code. The dispute arises when we have the concept of OID which in economic reality is interest, but not specifically denominated as such. It is therefore determined that semantics should not distort the rationale and purpose of the Code and that, in the fact situation before this Court, unamortized original issue discount on a note or debenture is indeed unmatured interest which is not an allowable claim under Code $\$ 502(b)(2)$.

Chateaugay, 109 B.R. at 55.

20. See, e.g., Kirschner et al., supra note 4, at 650-53; Nicholas P. Saggese et al., A Practitioner's Guide to Exchange Offers and Consent Solicitations, 24 LoY. L.A. L. REv. 527, 550 (1991) ("In other words, the rule protects the debtor and its other creditors from the assertion of claims for amounts in excess of the benefit actually conveyed to the debtor.").

21. See, e.g., Kirschner et al., supra note 4, at 645. 
exchange offer can generate original issue discount. ${ }^{22}$ Two years later, the Second Circuit held that bankruptcy policy favoring out-of-court settlement of claims dictates that an exchange offer does not generate original issue discount. $^{23}$ This Note proposes that an exchange offer can create original issue discount when the face amount of the new debt is greater than its market value at issuance, but that this recognition of OID does not kill the potential for successful out-of-court restructurings. This Note proposes that the negative incentive of OID recognition can be offset by positive incentives that facilitate workouts.

\section{The ChateaugaY DeCISION}

In July 1986, the LTV Corporation and sixty-six of its subsidiaries and affiliates filed for reorganization under Chapter 11 of the Bankruptcy Code. ${ }^{24}$ Prior to entering bankruptcy, LTV attempted an out-of-court workout through an exchange offer of old notes for new senior notes. ${ }^{25}$ After filing for bankruptcy, LTV moved pursuant to $\S 502(\mathrm{~b})(2)$ of the Bankruptcy Code for an order disallowing claims by holders of the new senior notes to the extent that such claims represented unmatured interest. ${ }^{26}$ Judge Lifland granted LTV's motion for partial summary judgment. ${ }^{27}$ In reaching this decision, Judge Lifland first looked to the economic substance of an exchange offer, concluding that original issue discount should arise and, second, argued that out-of-court workouts would not be unduly burdened by recognition of $\mathrm{OID}^{28}$

In his memorandum decision, Judge Lifland began by determining that original issue discount clearly represents unmatured interest and is not an allowable claim under $\S 502(\mathrm{~b})(2){ }^{29}$ Judge Lifland then considered whether an exchange offer could create OID. In deciding that it could, he relied on the memorandum opinion in In re Allegheny International, Inc. ${ }^{30}$ In Allegheny,

22. Chateaugay, 109 B.R. at 57 ("Consistent with the legislative history, the essential factor guiding this Court in making its determination of allowability is the underlying economic substance of the transaction.").

23. Chateaugay, 961 F.2d at 382-83. ("[G]iven Congress's intent to encourage consensual workouts and the obvious desirability of minimizing bankruptcy filings, we conclude that . . . no new OID is created in a face-value debt-for-debt exchange in the context of a consensual workout.").

24. 11 U.S.C. \$§ 1101-1174 (1994).

25. Chateaugay, 109 B.R. at 52. As of December 1932, LTV had issued a total face amount of $\$ 150,000,000$ of debentures with a coupon rate of $13.875 \%$ due December 1, 2002 (the "old notes"), for which it had received proceeds of $\$ 133,002,000$, or $88.67 \%$ of face value. In May 1986, LTV offered to exchange \$1000-face-amount 15\% senior notes due January 15, 2000 (the "new notes"), plus 15 shares of LTV common stock, for each $\$ 1000$ of old notes. As of June 1, 1986, old notes with a face amount of $\$ 116,035,000$ were exchanged for the new notes and the common stock, such that the face amount of the new notes issued was also $\$ 116,035,000$.

26. Id. at 53 .

27. Id. at 58 .

28. Id. at 56 .

29. $I d$. at 55 .

30. In re Allegheny Int'l, Inc., 100 B.R. 247 (Bankr. W.D. Pa. 1989). 
the issuer had offered debentures in exchange for preferred stock, ${ }^{31}$ and the court had held that original issue discount was created during the exchange to the extent that the face value of the new debentures exceeded the market value at which the new debt traded on the day after issuance, which was equal to the market price of the preference stock tendered. ${ }^{32}$ Although in Chateaugay the new debt was offered in exchange for old debt and in Allegheny the new debt had been offered in exchange for stock, Judge Lifland decided that Allegheny applied because the new notes were new securities, not merely modifications of the old debentures. ${ }^{33}$ Judge Lifland also relied on certain tax and accounting authorities to inform his view of the "underlying economic substance" of the transaction, ${ }^{34}$ although he conceded that "[t]he applicable treatment for tax or financial accounting purposes is not conclusive."35

The court gave weight to the fact that the exchange was voluntary, noting that the offering circular accompanying the exchange offer included a warning of the potential reduction in bankruptcy claims that could come from participating in such an exchange. ${ }^{36}$ Judge Lifland discounted the potential negative impact his ruling might have on out-of-court workouts. ${ }^{37}$

31. Id. at 248 . In 1977, Allegheny issued $5,466,093$ shares of $\$ 2.19$ cumulative preference stock. In 1984, Allegheny offered to exchange one subordinated $10.4 \%$ debenture due July 1,2002 for each share of preference stock. Id.

32. Id. at 253.

33. Chateaugay, 109 B.R. at 56 (stating that considering the exchange "a 'bookkeeping' entry that should not be accorded any economic or legal significance. ..." is a "strained interpretation of the facts [that] flies in the face of even a cursory reading of the instruments. Maturity dates, interest rates, and sinking fund requirements have all been changed in the New Notes.").

34. Id. at 55.

35. Id. at 57. Judge Lifland cited I.R.C. $\$ 1273(\mathrm{~b})$, which requires debtors to recognize OID in initial debt offerings. See Chateaugay, 109 B.R. at 55. At the time of the Lifland decision, I.R.C. $\$ 1275(a)(4)$ governed debt issued in an exchange transaction and did not require recognition of OID. See Saggese et al., supra note 20 , at 552 n.l12. Since the Lifland decision, $\$ 1275(a)(4)$ has been repealed, and debtors are required to recognize OID during an exchange. See Omnibus Budget Reconciliation Act of 1990, Pub. L. No. $101-508, \S 11325$ (a)(2), 104 Stat. 1388, 1388-466 to -467 . Judge Lifland also cited APB OPINION No. 21 (Am. Inst. of CPAs 1971), which requires recognition of OID on debt issued but does not apply to debt issued during an exchange offer. See Chateaugay, 109 B.R. at 55. The proper authority is StATEMENT of Financial Accounting Standards No. 15 (Fin. Accounting Standards Bd. 1977) (FAS15), which typically does not allow recognition of OID during exchange offers. Id. $\mathbb{1} 16$. However, when additional consideration such as equity is offered, as in the Chateaugay case, FAS15 requires OID to be recognized. Id. II 19.

36. Chateaugay, 109 B.R. at 56. The relevant discussion of such risks in the offering circular dated May 1, 1986 read:

"Consummation of the Exchange Offer may have significant bankruptcy consequences for holders of New Securities. In general, a note, bond or debenture represents a potential bankruptcy claim equal to its face amount, plus accrued and unpaid interest through the date of commencement of the bankruptcy case, less unamortized original issue discount, if any .... To the extent that the Exchange Offers involve the issuance of New Notes at an original issue discount, exchanging holders may have a smaller bankruptcy claim immediately thereafter than at present."

Id. (quoting offering circular).

37. Judge Lifland pointed to the offering circular in claiming that "a lesser or greater than felicitous treatment of specific claims in bankruptcy has always played a part in 'workouts', and undoubtedly participants will continue to carefully weigh the risks and rewards to be gained from such efforts." Id. at 56 (footnote omitted). However, Judge Lifland did not offer any additional support for the claim that 
Furthermore, he rejected the respondent's contention that his ruling would necessarily extend to create OID in other instances such as compromised trade debt; he rebuffed that concern by stating that the treatment of notes or debentures is not analogous to the treatment of all other obligations. ${ }^{38}$

Judge Lifland concluded by examining the concept of "interest" and recognizing that interest is simply compensation for the use of money. According to Judge Lifiand, under circumstances in which the face amount of new debt exceeds the market value of the debt that was exchanged, the difference is simply an analogous form of compensation. Hence, Judge Lifland determined that the new notes were essentially bonds with original issue discount. $^{39}$

For example, assume Company $A$ issued bonds with $\$ 1000$ face amount, not in exchange for $\$ 700$ in cash, but in exchange for old securities with a market value of $\$ 700$. Under Judge Lifland's ruling, holders of the newly issued securities would have a claim of $\$ 700$ in bankruptcy because the value tendered for the new securities was worth $\$ 700$ at the time of purchase. The $\$ 300$ difference represents original issue discount.

\section{CRIticism OF ChateaugaY AND SubSequent Reversal}

The Chateaugay opinion was greeted with outrage by economists, legal scholars, and the popular press. With striking unanimity, those critics claimed that the ruling would stifle out-of-court workouts and would inevitably lead to greater numbers of costly bankruptcy proceedings. They strongly urged that the case be overruled on appeal. ${ }^{40}$ The Second Circuit obliged. After the district court affirmed, ${ }^{41}$ the Second Circuit reversed in April 1992, claiming that no original issue discount is created in face-value debt-for-debt exchanges. ${ }^{42}$ The court based its ruling primarily on the bankruptcy policy of promoting out-of-

workouts tend to produce unfavorable bankruptcy results for workout participants, regardless of OID treatment.

38. Id.

39. Id. at 56-57. Judge Lifiand wrote:

Consistent with the legislative history, the essential factor guiding this Court in making its determination of allowability is the underlying economic substance of the transaction. Under the circumstances presented here this Court finds that the New Notes and the Old Debentures were issued at a discount and that the discount represented unmatured interest.

Id. at 57.

40. See, e.g., Coombs, supra note 10, at 673 ("The LTV decision is wrongly decided."); Saggese et al., supra note 20, at 549 (stating that "[t]he result reached in the LTV decision is inappropriate and extremely unfair"); Lawrence A. Weiss, The Bankruptcy Code and Violations of Absolute Priority, J. APPLIED CORP. FIN., Summer 1991, at 71, 78 ("[T] LTe LTV case should be reversed or changed by Congress.").

41. Chateaugay, 130 B.R. 403 (S.D.N.Y. 1991).

42. Chateangay, 961 F.2d 378, 382-83 (2d Cir. 1992). 
court workouts. ${ }^{43}$ Two months later, the Fifth Circuit reached a similar conclusion in Texas Commerce Bank v. Licht (In re Pengo Industries). ${ }^{44}$

Critics of the bankruptcy court's Chateaugay decision argued that recognition of OID during an exchange offer inappropriately penalized creditors willing to cooperate in the workout process. Because only the creditors who participated in a workout would have their claims marked to market, while holdouts would have unaltered claims, critics maintained that the Chateaugay decision would give uncooperative creditors a windfall at the expense of those who tender. ${ }^{45}$ These writers unanimously argued that Chateaugay was wrongly decided because it penalized participation in exchange offers. ${ }^{46}$ Critics also argued that the bankruptcy court misinterpreted the economic substance of the exchange offer, claiming that a face-value exchange offer does not alter the fundamental economic relationship between the debtor and its bondholders. ${ }^{47}$ Moreover, these critics charged that the bankruptcy court ruling was unworkable because it would necessarily extend to all payment modifications. In accordance with the wishes of these writers, the Second Circuit reversed the bankruptcy court decision. The Second Circuit was apparently highly influenced by the vocal critics of the Chateaugay decision; the court repeatedly cited the writings of Marc Kirschner and others in the reversal. ${ }^{48}$

The Second Circuit opinion, penned by then-Chief Judge Oakes, began by upholding the lower court's determination that original issue discount represents unmatured interest under $\S 502(b)(2)$, specifically citing the legislative history of that portion of the Code. ${ }^{49}$ Thus, the court concluded that the OID on the old debentures was not an allowable claim. But the court parted company with Judge Lifland on the issue of creation of OID in the exchange offer and determined that no additional OID was created by the debtfor-debt exchange. ${ }^{50}$ In reaching its conclusion, the court looked primarily to

43. Id. See In re Colonial Ford, 24 B.R. 1014, 1015-17 (Bankr. D. Utah 1982), which offers a detailed analysis of how the Bankruptcy Code promotes out-of-court workouts. "Congress designed the Code, in large measure, to encourage workouts in the first instance, with refuge in bankruptcy as a last resort." Id. at 1015. Also see the legislative history of the Bankruptcy Code, H.R. REP. No. 595, 95th Cong., 1st Sess. 220 (1977), reprinted in 1978 U.S.C.C.A.N. 5963, 6179-80 ("Most business arrangements, that is, extensions or compositions (reduction) of debts, occur out-of-court. The out-of-court procedure, sometimes known as a common law composition, is quick and inexpensive." (footnote omitted)).

44. 962 F.2d 543, 546-51 (5th Cir. 1992).

45. See Kirschner et al., supra note 4, at 658; Saggese et al., supra note 20, at 549-50.

46. See Coombs, supra note 10, at 659; Epling, supra note 9, at 46-47; Kirschner et al., supra note 4 , at 658; Saggese et al., supra note 20 , at 549 .

47. See Kirschner et al., supra note 4 at 656 ("[S]ince Chateaugay involved a face value exchange, the actual liability of the debtor to its old and new bondholders remained the same . ..."); Saggese et al., supra note 20 , at $550-51$ ("[T] exchange... has nothing to do with the value the debtor received from the issuance of the target debt security.").

48. See Chateaugay, 961 F.2d at 381-83.

49. See id. at 380-81; see also supra note 18 and accompanying text (legislative history of $\$ 502(b)$ ).

50. See id. at 382-83. 
the policy of promoting out-of-court workouts but also assessed the economic substance of a face-value debt-for-debt exchange as a maintenance of an existing debt. ${ }^{51}$

The court distinguished a "market value exchange" from a "face value exchange," the difference being that in a market-value exchange the new bonds have a "reduced principal," while in a face-value exchange the new bonds do not alter the face amount of the old securities. ${ }^{52}$ Judge Oakes adopted the distinction between so-called face-value and market-value exchanges that was developed in the Kirschner article, paraphrasing Kirschner in the opinion. ${ }^{53}$ The court classified the exchange made by LTV as a face-value exchange because the principal amount due at maturity of the new notes remained unaltered, notwithstanding that the coupon rate and date of maturity did change. $^{54}$

After acknowledging that the bankruptcy court had used the plain meaning of original issue discount in its opinion," Judge Oakes stated that "the bankruptcy court's logic ignores the importance of context, and does not make sense if one takes into account the strong bankruptcy policy in favor of the speedy, inexpensive, negotiated resolution of disputes." Kirschner, the appeals court claimed that the bankruptcy court ruling would discourage creditors from cooperating in a workout by reducing the claims of cooperating creditors in bankruptcy in a manner that would unfairly grant a windfall to holdouts who do not tender. ${ }^{57}$ The court held that a reversal of the

51. See id.

52. Id. at 381-82.

53. See id. at 382; Kirschner et al., supra note 4, at 645-47. Kirschner stated:

Typically, one of two strategies is adopted in exchange offers for public debt. The first is an attempt to capture the market "discount" that debentures may be trading at in the marketplace by offering to exchange an existing debt instrument for a new debenture with a reduced principal amount - the "fair market value exchange." The second is an attempt to extend and/or modify payment terms of existing debentures, but not reduce their principal amount, in order to allow the troubled company more time to recover from its financial problems-the "face value exchange."

Id. at $645-46$.

54. Chateaugay, 961 F.2d at 382.

55. See id. ("The bankruptcy court's . . . application of the definition of OID to exchange offers may seem irrefutable at first glance ....").

56. Id.

57. Id. Kirschner wrote:

[T] he Chateaugay decision exacerbates the holdout problem in an exchange offer by penalizing those creditors who do participate in an exchange offer and providing even greater rewards for those who do not. By revaluing only the face value exchang[e]r's claim downward while leaving the holdout's claim intact, the court creates a windfall for the non-exchanging holdout in a subsequent bankruptcy. The result also creates a windfall for the company by relieving its debt measured by the additional OID. Thus, Chateaugay gives creditors a disincentive to cooperate with a struggling debtor in a consensual workout and gives an artificial benefit to the debtor.

Kirschner et al., supra note 4 , at 658 . 
bankruptcy court decision was necessary if exchange offers were to be a viable alternative to Chapter $11 .^{58}$

The court recognized that a market-value exchange could reduce a bankruptcy claim, but the court stated that a face-value exchange does not create OID because the exchange "does not change the character of the underlying debt, but reaffirms and modifies it." $"$ The court concluded that the economic substance of a face-value debt-for-debt exchange-as opposed to a market-value exchange-is not a reduction in liability, and held that OID cannot be generated where there is no underlying change in liability ${ }^{60}$ Thus, Judge Oakes distinguished the Allegheny case, which involved a debt-for-stock exchange that increased the company's liability, from the LTV case, in which the company's liability remained unchanged. ${ }^{61}$ Finally, the Second Circuit refused to apply tax authorities to determine the appropriate bankruptcy policy toward OID. Once again referring to the Kirschner article, the court stated that the "tax treatment of a transaction ... need not determine the bankruptcy treatment." ${ }^{\prime 2}$ The court concluded that since the legislative history of $\S 502(\mathrm{~b})$ did not explicitly require recognition of OID in a face-value exchange, the court would not infer such a catastrophic intention. ${ }^{63}$

For example, assume Company $A$ issued bonds with a $\$ 1000$ face amount in exchange for old securities with a market value of $\$ 700$ and a face amount of $\$ 1000$. Under the Second Circuit ruling, holders of the newly issued securities would have a claim of $\$ 1000$ in bankruptcy because the new securities have a face amount of $\$ 1000$. The $\$ 300$ difference in value between the face amount of the new securities and their market value would not be recognized as OID.

58. Chateaugay, 961 F.2d at 382 . On that point, the court cited articles by Coffee and Klein and by Kirschner. Coffee and Klein wrote that the bankruptcy court decision would "chill exchange offers" because "Ib]y accepting the exchange offer, the creditor sacrifices the difference between the face amount of the securities given up and the lesser fair market value of the securities received." Coffee \& Klein, supra note 9, at 1249 n.121. Kirschner noted that "[t]he Chateaugay decision has made it far less attractive for public debt holders to participate in a proposed face value exchange by, in effect, penalizing such holders for their participation." Kirschner et al., supra note 4, at 647.

59. Chateaugay, 961 F.2d at 382.

60. Id.

61. Id. at 383 .

62. Id. Kirschner wrote:

While the bankruptcy laws are concerned with maintaining the relative differences in status and priority among similarly situated creditors, the tax laws are concerned with establishing a consistent system of accounting for increases and decreases in wealth of discrete taxpayers, in order to impose a tax on their respective net increases.

He added that the tax system is based on realization events, and the exchange offer is one such event. "Therefore, although an exchange offer may present a proper time to tax the participants, that fact is not relevant in the bankruptcy analysis of the relationship that similarly situated creditors have to one another and to the debtor." Kirschner et al., supra note 4, at 656.

63. 961 F.2d at 383. Judge Oakes wrote that the court, "[i]n the absence of unambiguous statutory guidance, ... . will not attribute to Congress an intent to place a stumbling block in front of debtors seeking to avoid bankruptcy with the cooperation of their creditors." Id. 
The Fifth Circuit, citing nearly the same authorities that appeared in the Second Circuit's opinion, reached an identical conclusion with respect to facevalue debt exchanges. The facts of the Pengo case, however, differed somewhat from the LTV case. ${ }^{64}$ In Chateaugay, old debentures were tendered for new, senior interest-bearing securities plus common stock, whereas in the Pengo case old debentures were exchanged for two senior classes of convertible, non-interest-bearing securities. In both instances, however, the appellate courts considered the transactions to be face-value exchanges because the face value of new debt was the same as that of the old, and held that no OID could be created in such face-value exchanges. ${ }^{65}$

\section{RESOLVING THE CONFLICT BETWEEN THE ECONOMICS OF EXCHANGE OFFERS AND BANKRUPTCY POLICY FAVORING WORKOUTS}

This Note suggests that the proper legal treatment of OID generated during an exchange offer should (1) faithfully reflect the underlying economic substance of the transaction and (2) maintain the viability of out-of-court restructurings. It argues that the Second and Fifth Circuits erroneously abandoned a literal interpretation of original issue discount in a noble effort to promote the efficacy of exchange offers. In fact, their rulings are based on faulty assumptions and create more problems then they solve. Original issue discount occurs whenever the face value of a newly issued obligation exceeds the value surrendered in payment for it. This Note claims that it is appropriate to recognize OID whether the new obligation is purchased with cash or by surrendering old securities. This Note suggests that the recognition of OID created during an exchange is both true to the economic substance of the

64. See Pengo, 962 F.2d at 544-45. In 1980, Pengo Finance issued $\$ 22,500,000$ of $8.5 \%$ convertible debentures due in 1995. The debentures were purchased at their face value, i.e., with no OID. In 1983, neither Pengo Finance nor its guarantor, Pengo, could make the interest payments on the old debentures. In 1985 , Pengo Finance offered to exchange one $\$ 500$-face-amount Class A debenture and one $\$ 500$-faceamount Class B debenture, neither of which bore interest, for each $\$ 1000$-face-amount old debenture. The new debentures were senior to the old debentures, they matured in 1991 (four years earlier than the old debentures), and they could be converted for Pengo's common stock more favorably than the old debentures. Approximately 59\% of the old debentures were tendered, but in late 1988 and early 1989 involuntary petitions for relief under Chapter 11 were filed against Pengo. Id.

65. Id. at 547-49. ("The 1989 bankruptcy court decision of In re Chateaugay created an enormous disincentive for investors to participate in consensual out-of-court restructurings and, thus, spurred movement of financially troubled companies into the bankruptcy courts."). The Fifth Circuit, with analysis similar to the Second, rejected the Chateaugay bankruptcy court ruling on policy grounds and relied heavily on the published writings of legal scholars, noting that Judge Lifland's decision "produced a swift response from commentators who aggressively scrutinized its analysis of the original issue discount question in the face value exchange context and observed its effect on consensual out-of-court restructurings." Id. at 548. The Fifth Circuit also declined to decide whether OID could be created in a fair-market-value exchange, which it defined as a transaction in which "the holders exchange a debt instrument for a new debt instrument with a lower face amount." Id. at 550. The court held that the exchange of non-interest-bearing securities for interest-bearing securities represented a face-value exchange when the principal due at maturity remained unchanged. Id. at 547. Also, the Fifth Circuit indicated that the tax treatment of debt exchanges is not informative in the bankruptcy context. Id. at 550-51. 
transaction and is unnecessary to advance the goal of promoting out-of-court workouts.

Section A of this part argues that the Second and Fifth Circuits, and the commentators on which they relied, appear to have ignored the economic substance of exchange offers. A debtor attempts an exchange offer because it is unable to meet its obligations to bondholders in a timely fashion. In an exchange offer, creditors agree to reduce their claims against the debtor, usually through an extension of payment terms, because they understand that in a bankruptcy proceeding they would likely receive even less value for their bonds. The end result of such an exchange offer is that the debtor reduces its payment obligations to creditors who exchange. Otherwise, it would have been pointless for the debtor to undertake such an offer. ${ }^{65}$ The economic substance of any exchange offer is thus a reduction in liability.

The distinction that Kirschner and the courts of appeals drew between face-value exchanges and market-value exchanges is truly a distinction without a difference. The appellate courts erroneously concluded that an exchange offer with original issue discount, the face-value exchange, is fundamentally different from an exchange offer with no OID, the market-value exchange. In reality, the economic substance of both types of exchange is a reduction in liability. By holding that a face-value exchange cannot create OID, the appellate courts promulgated a legal rule that contradicts the Code's prohibition on valuing claims by the face value of a security. Unfortunately, the Second and Fifth Circuits have likely opened the door for needless litigation over an economic triviality, the face value of a bond.

Section B proposes that the value surrendered in payment for a debt obligation, not the face amount of the obligation, should determine the bankruptcy claim associated with the obligation. Whereas the courts of appeals value the claims of debt issued in an exchange offer by the face amount of the new debt, the appropriate bankruptcy claim valuation is the market value surrendered in payment. However, if there is no forfeiture of the holder's rights under an obligation, and the old obligation simply undergoes a modification or extension, the creditor's bankruptcy claim should not be altered because the creditor did not purchase a new obligation. Thus, only when a creditor surrenders all rights under an obligation in exchange for a new obligation should the bankruptcy claim be marked to market. Any concern that the bankruptcy court decision would necessarily apply to all liability

66. See, e.g., Epling, supra note 9, at 17. Epling noted:

In general, three types of exchange offers exist: a composition, where debt or interest rates are written down; an extension, where maturities and amortizations are extended; and a cash tender, where the bonds are exchanged for some number of cents on the dollar. Of course, an exchange also can involve combinations of these three basic options. The purpose ... stems ... from Id. debt service which is outstripping cash flow. 
restructurings is mistaken. This Note proposes a limitation of Judge Lifland's ruling to instances in which a new security is created and a novation has occurred; contract, tax, and securities law already detail when such a new security is created. ${ }^{67}$

Section $\mathrm{C}$ argues that the reversal of the bankruptcy court's decision in Chateaugay was both insufficient and unnecessary to advance the policy goal of promoting out-of-court workouts. It proposes that the holdout problem can best be eliminated through the exchange of new securities that are contractually senior to the old debt and through the enforcement of this payment priority in bankruptcy proceedings. Creditors would continue to participate in exchange offers without the reversal of Chateaugay as long as participation was the best strategy to recover maximum value for their investment. If, as in Chateaugay, the new securities issued were contractually senior to the securities that were exchanged, holdouts would appropriately be penalized by a decrease in their probability of recovery should the debtor later enter bankruptcy.

\section{A. Face-Value Versus Fair-Market-Value Exchanges- An Erroneous Distinction}

Both the Pengo and Chateaugay circuit court decisions relied heavily on the determination that the exchange offers at issue were "face value" exchanges. ${ }^{68}$ Both opinions cited Kirschner's Deleveraging Tool article as the source of the definition of a face-value exchange, as opposed to a fair-marketvalue exchange. Kirschner wrote that relatively healthy companies undertake face-value exchanges to relieve problems with short-term liquidity. As such, a face-value exchange "is an attempt to extend and/or modify payment terms of existing debentures, but not reduce their principal amount, in order to allow the troubled company more time to recover from its financial problems." ${ }^{169}$ In contrast, a fair-market-value exchange purportedly capitalizes on the reduced price at which old debentures are trading. In such an exchange, a new debenture is issued "with a reduced principal amount," which enables a company "to reduce its overall debt obligations."70

Kirschner's distinction between face-value exchanges and fair-market-value exchanges rests on the narrow issue of whether the new debt has the same principal amount as the old. However, there is no legitimate basis for placing such enormous weight on so irrelevant a distinction. One can construct a bond with any face amount and with any given market value by modifying the

67. See infra notes 89-101 and accompanying text.

68. Pengo, 962 F.2d at.549; Chateaugay, 961 F.2d at 382.

69. Kirschner et al., supra note 4 , at 646-47.

70. Id. at 646 . 
coupon rate and the date of maturity. ${ }^{71}$ Any "fair market value" exchange contemplated by Kirschner could easily be changed to a "face value" exchange, without altering the debt burden, by increasing the face amount of the new bonds and lowering the coupon rate, i.e., by increasing the original issue discount on the new bonds. For example, assume Company A wishes to restructure outstanding bonds with $\$ 1000$ face amount and $\$ 700$ market value. If Company $A$ offered $\$ 1000$-face-amount bonds with a $\$ 700$ market value, the exchange would be considered a "face value" exchange. If Company $A$ offered $\$ 700$-face-amount bonds with a $\$ 700$ market value, the exchange would be considered a "market value" exchange.

Both face-value and market-value exchanges reduce the liability of the debtor, though in face-value exchanges the new obligations have original issue discount equal to the difference between the market value of the old securities and the face amount of the new ones. Under the Kirschner face-value/marketvalue distinction, there is no reduction in bankruptcy claims from face-value exchanges, while there is a claims reduction from market-value exchanges. By stating that the value of a claim should be determined "notwithstanding the face amount,"72 however, the legislative history of Bankruptcy Code $\S 502(\mathrm{~b})$ (2) specifically guards against letting the face amount of an obligation determine the amount of the claim. Congress fully understood the gross inequity of treating differently two creditors who paid the same amount for a bond simply because one creditor purchased a bond with more original issue discount. By promulgating a legal rule that prefers the purchasers of discounted bonds, the courts of appeals have directly contradicted the legislative history of the statute they interpreted.

Both the Pengo and Chateaugay appellate court decisions are excellent examples of how difficult it is to apply the supposed distinction between a "fair market value" exchange and a "face value" exchange. Kirschner wrote that, in a fair-market-value exchange, bondholders typically receive "at least some additional consideration (such as equity in the company) as an inducement to tender." ${ }^{\text {"3 }}$ In Chateaugay, the exchange offer included not just bonds of the same face value but also fifteen shares of common stock. ${ }^{74}$ The court of appeals disregarded this fact, however, and maintained its assertion that the transaction was a face-value exchange. Perhaps the fifteen shares were not enough additional consideration to push the transaction to the market-value exchange category; by not articulating any standard for bankruptcy judges to

71. See, e.g., VAN HORNE \& WACHOWICZ, supra note 15, at 77-79 (demonstrating how varying coupon rate generates bonds with value greater or less than face value).

72. H.R. REP. No. 595, 95th Cong., Ist Sess. 352-53 (1977), reprinted in 1978 U.S.C.C.A.N. 5963, 6308-09; see supra note 18.

73. Kirschner et al., supra note 4 , at 647 .

74. Chateaugay, 961 F.2d at 380. 
use, the Second Circuit opened the door for senseless litigation over how much additional consideration constitutes a market-value exchange transaction.

The Pengo court held that the exchange of interest-bearing securities for non-interest-bearing securities is a face-value exchange because "the overall debt obligation of the company has not been altered." 75 But the agreement of creditors to forgive interest payment on debt is every bit as much a reduction in "debt obligation" from the debtor's perspective as it is when creditors accept a reduction in principal. The existence of efficient capital markets to borrow and invest funds requires this be true. ${ }^{76}$ Therefore, distinguishing "face value" exchanges from "market value" exchanges by whether the debt level has been reduced is impossible.

Both appellate courts declined to rule whether a reduction in claims may occur in a market-value exchange, although the Second Circuit noted that marking claims to market in such circumstances "might make sense." If the courts of appeals are to be consistent with the analysis of Kirschner that they relied on for their treatment of face-value exchanges, however, then a market valuation in bankruptcy of market-value exchanges would necessarily follow, because in a market-value exchange the debtor "is able to reduce its overall debt obligations." ${ }^{78} \mathrm{~A}$ market-value exchange is the functional equivalent of repurchasing outstanding debt on the open market and funding the repurchase by issuing new bonds. ${ }^{79}$ Therefore, in bankruptcy, holders of the new bonds from a market-value exchange would have claims only equal to the cash value of the old bonds that were tendered because the exchange of the old bonds was economically equivalent to a cash purchase. ${ }^{80}$

Furthermore, no court could allow a claim in bankruptcy that is greater than the payment requirement of the debt obligation in question. For example, assume that Company $A$ previously issued at par $\$ 1000$-face-amount notes that now have a market value of $\$ 700$. Company $A$ exchanges these notes for $\$ 700$ face-amount notes with a market value of $\$ 700$. At maturity the $\$ 700$-faceamount notes will pay $\$ 700$; thus, the maximum claim that would be allowable in bankruptcy pursuant to Bankruptcy Code $\S 1124$ for the holder of such an obligation would be $\$ 700$. Courts are therefore very likely to rule that holders of bonds issued in a market-value exchange have claims in bankruptcy equal to the market value of the bonds that are tendered. There is thus the potential

75. Pengo, 962 F.2d at 548 (quoting Kirschner et al., supra note 4, at 647).

76. The value of debt is equal to the sum of discounted value of the stream of coupon payments and principal. A reduction in face amount or coupon rate therefore reduces debt. See, e.g., VAN HORNE \& WACHOWICZ, supra note 15 , at 76-80.

77. Chateaugay, 961 F.2d at 382.

78. Kirschner et al., supra note 4 , at 646.

79. Cf. id. at $645-46$ (describing a market-value exchange as "an attempt to capture the market 'discount' that debentures may be trading at in the marketplace by offering to exchange an existing debt instrument for a new debenture").

80. For a discussion of the valuation of such claims, see supra notes 17-20 and accompanying text. 
for pointless litigation over whether a transaction was a face-value exchange or a market-value exchange, and it will be impossible to create a legal rule that could appropriately distinguish between the two. A face-value exchange is nothing more than a market-value exchange with original issue discount. Therefore, because market-value exchanges require market valuation of claims in bankruptcy, and face-value exchanges are economically indistinguishable from market-value exchanges, face-value exchanges should have market valuation of claims in bankruptcy, as they did in Judge Lifland's decision.

Moreover, in promulgating a legal rule based on the economically irrelevant face-value/market-value distinction, the appellate courts have promoted exchange offers of identical face values over other exchange offers that may receive less preferential treatment in bankruptcy. In an exchange offer, bondholders would be willing to pay a higher amount for bonds of the same face value relative to bonds of lower face value that, in the absence of the appellate rulings, would have had the same market value. There is no policy reason why a court should encourage companies to offer more or less original issue discount on bonds in exchange offers. The court should allow debtors to restructure debt with payment terms that best match their forecasted liquidity. Kirschner recognized that companies commence exchange offers with more or less original issue discount depending on the reason for the restructuring. ${ }^{81}$ Companies will enter so-called face-value exchanges, with a reduction in coupon rate and/or extension of maturity, when current interest expense is outstripping cash flow, but will enter market-value exchanges, with reduction in principal amount, when repayment of principal is too burdensome. ${ }^{82}$ The Chateaugay reversal effectively precludes any exchange offer with a reduction in principal amount, however, because such exchanges would have less favorable treatment in bankruptcy relative to exchanges with the same face value. For a company otherwise best suited to a "market value" exchange, the Chateaugay reversal may lead to unnecessary financing, tax, and hedging costs when the obligation terms of the restructuring are not properly matched with the company's expected cash flow.

\section{B. The Slippery Slope Fallacy}

A concern of many of the Chateaugay bankruptcy decision's critics was that the ruling necessarily extended to all payment modifications. ${ }^{83}$ Specifically, commentators suggested that for Chateaugay to be logically consistent, original issue discount must be recognized whenever a creditor's claim is adjusted, such as in a debt extension. ${ }^{84}$ This concern is unfounded,

81. Kirschner et al., supra note 4 , at $645-47$.

82. Id.

83. See Epling, supra note 9, at 44; Kirschner et al., supra note 4, at 657.

84. See Kirschner et al., supra note 4, at 657-58. 
however, because Chateaugay only applied to exchange offers that created a new security. Original issue discount recognition should only occur in such instances when a security is originally issued. If a payment modification does not create a new security, it is improper to recognize OID.

A holder of a debt instrument should be treated the same whether the instrument was purchased with cash or by surrendering an old security. It is appropriate to recognize original issue discount whenever the value surrendered in payment is less than the face amount of the new obligation. However, if a debt restructuring does not entail the surrender of an old obligation and the purchase of a new one, the restructuring should not alter the bankruptcy claim of the holder of the debt instrument because the restructuring does not create a new liability.

It may be argued that all payment modifications, whether creating a new security or not, result in a decrease in the debtor's indebtedness because of a reduced debt service burden. At first blush, the recognition of OID only when a new security is created may therefore appear arbitrary. However, only when a new obligation is created and the old obligation is extinguished is a company receiving new value. Because payment modifications not constituting a new security do not forgo the right to collect under the old security, the corporation has received no new value from the creditor. As claims in bankruptcy are only permitted for the value tendered to the debtor (plus any accrued interest), it is therefore only appropriate to value a claim by the prior market value of a security when such previously existing security was surrendered as payment for a new obligation. Thus, OID recognition is appropriate only when the face amount of a new security exceeds the value surrendered in payment. Under the Second Circuit rule, however, no OID is recognized in face-value exchanges even though the debtor has received in payment for the new obligation an instrument worth less than the new instrument's face value.

The interpretation of an exchange offer as a novation and an issuance of a new security can be used to distinguish inapposite scenarios that critics of the bankruptcy court in Chateaugay claimed necessarily followed from Judge Lifland's ruling. Critics charged that his holding could impede attempts of debtors and creditors to modify the terms of any obligation and could create needless litigation as to what constitutes original issue discount. ${ }^{85}$ For example, critics posited that for Judge Lifland's analysis to be consistent it must also apply to the renewal of notes or the extension of a loan. ${ }^{86} \mathrm{Such}$

85. See Coombs, supra note 10 , at 664 ; Saggese et al., supra note 20 , at 551.

86. See Epling, supra note 9, at 44 (arguing that debt exchanges should be treated the same as debt extensions); Kirschner et al., supra note 4, at 657-58 ("[T]aken to its logical extreme . . . the Chateaugay analysis could . . . require that every general unsecured creditor's claim that has been modified or otherwise adjusted be fixed at the fair market value of that claim on the date of bankruptcy."); Phelan \& Jernigan, supra note 10, at 61 ("[O]ne must also apply the concept [described in Chateaugay] to all other creditors, including banks and other holders of claims that renew notes or extend obligations."). 
concern is unfounded, for Judge Lifland's opinion applied solely to exchange offers in which an entirely new obligation is created, not ones in which an old obligation has been modified. ${ }^{87}$ Therefore, exchange offers can readily be distinguished from other debt payment modifications, e.g., the restructuring of a loan, in which no novation occurs and no separate obligation is created. Where there is no new obligation, no new OID need be recognized. It is not unworkable, as critics allege, for Chateaugay to apply only to such instances in which a new security is indeed issued.

In an exchange offer, a creditor agrees to surrender a preexisting security for newly issued debt in satisfaction of the previous claim. ${ }^{88}$ Such a voluntary substitution of one obligation for another constitutes a novation. Four elements are required for a novation to take place: (1) a previous valid obligation; (2) an agreement of all the parties to extinguish the old contract; (3) a valid new contract; and (4) agreement of the parties to the new contract. ${ }^{89}$ In a debt-fordebt exchange offer, all of the elements of a novation are clearly met. First, the old debt that is exchanged is a valid contract. Second, issuance of new debt is conditioned on the surrender of the old debt in the exchange and a waiver of the right to payment under the old securities. Third, the newly offered debt is a valid contract. Fourth, in an exchange offer, both parties agree to accept the payment terms of the newly issued securities. Thus, the surrender of old debt for new debt in the context of an exchange offer clearly results in a novation.

Payment modifications such as the extension of a loan or a renewal of a note do not result in a novation. It is well-settled law that the giving of a new note for a debt evidenced by a former note does not extinguish the old note unless such is the intention of the parties..$^{90}$ In a consummated debt tender offer the intent to substitute one security for another can be clearly inferred, but in a loan modification agreement such intent is lacking.

Similarly, securities law and tax law both consider a debt-exchange offer to be a sale of a new security, not an alteration of an existing security, while the extension of a loan is not." This further conflicts with the Second Circuit's assertion that a debt-for-debt exchange "reaffirms and modifies"

87. Chateaugay, 109 B.R. at 56 (stating that decision does not apply to "all other kinds of obligations of the debtor including compromised trade debt and trade discounts").

88. See Ford Lacy \& David M. Dolan, Legal Aspects of Public Debt Restructurings: Exchange Offers, Consent Solicitations and Tender Offers, 4 DEPAUL BuS. L.J. 49, 50 (1991). 1977).

89. See, e.g., Town \& Country Linoleum \& Carpet Co. v. Welch, 392 N.Y.S.2d 517, 518 (App. Div.

90. See, e.g., First Nat'l Bank \& Trust Co. v. Daniel, 701 F.2d 141 (11th Cir. 1983).

91. Securities Act of 1933,15 U.S.C. $\$ 77(b)(3)$ (1994). Case law has clearly established that the exchange of a new security for an existing security constitutes a "sale" under the Securities Act because the economic relationship between debtor and creditor is thereby fundamentally altered. See United States v. Wernes, 157 F.2d 797, 799 (7th Cir. 1946); United States v. Riedel, 126 F.2d 81, 83 (7th Cir. 1942); see also Rev. Rul. 73-160, 1973-1 C.B. 365 (controlling whether taxable exchange of securities occurred); 17 C.F.R. $\S 230.145$ (1995) (controlling when alteration of security creates new security within meaning of $\S 2(3)$ of Securities Act). 
existing debt. ${ }^{92}$ Section 2(3) of the Securities Act defines "sale" as including "every contract of sale or disposition of a security or interest in a security, for value." ${ }^{.93}$ Although the definition of sale does not explicitly include an exchange, courts have found the exchange of securities to be a sale. ${ }^{94}$ Moreover, the existence of $\S 3(a)(9)$ and 3(a)(10), which exempt certain types of exchanges from the Securities Act, evidences Congress's view that an exchange of securities is a sale. ${ }^{95}$ It is clear that a sale occurs when a security holder voluntarily surrenders the instrument and receives an entirely different instrument. ${ }^{96}$ In addition, the alteration of a security effectively creates a new security when the alteration has substantially affected the legal rights and obligations of the outstanding securities. ${ }^{97}$

For tax purposes, a debt-for-debt exchange offer is a realization event in which cancellation-of-indebtedness income may arise. ${ }^{98}$ Tax law considers the material modification of a debt instrument to be an exchange of debt instruments. ${ }^{99}$ Thus, a change in interest rate, taken alone or in combination with a change in maturity, will generally be deemed to be an exchange, ${ }^{100}$ whereas a payment extension will generally not be deemed to be one. ${ }^{101}$

Moreover, the creation/modification dichotomy proposed in this Note is a far more tenable distinction for determining recognition of OID during an exchange offer than the face-value/market-value dichotomy proposed by Kirschner. Whereas the distinction between the creation of a new security and the modification of an old security is based on established principles of law, the face-value/market-value distinction runs directly counter to the bankruptcylaw mandate to value claims irrespective of their face amount. The creation/ modification distinction is perhaps as economically trivial as the facevalue/market-value distinction, because both debt exchanges and debt modifications reduce indebtedness. However, the creation/modification distinction is a necessary byproduct of a legal world that differentiates between new and preexisting relationships.

92. Chateaugay, $961 \mathrm{~F} .2 \mathrm{~d}$ at 382.

93. 15 U.S.C. \& 77b(3) (1994).

94. Riedel, 126 F.2d at 83 ("[O]ne may sell a security and be paid therefor in cash, or in another security, or in any other object of value such as a house....").

95. 15 U.S.C. \& 77c(a)(9)-(10) (1994); see RICHARD W. JENNINGS \& HAROLD MARSH, JR., SECURITIES REgulation CASES AND MATERIALS 399 (6th ed. 1987).

96. See JENNINGS \& MARSH, supra note 95 , at 399.

97. See Philip Palmer McGuigan \& William P. Aiken, Jr., Amendment of Securities, 9 REv. SEC. REG. 935, 935 (1976).

98. I.R.C. $\$ 108(\mathrm{e})(10)$ (1994). Section 108(e)(10) provides that, for purposes of determining cancellation of indebtedness income, a debtor issuing an instrument in satisfaction of indebtedness "shall be treated as having satisfied the indebtedness with an amount of money equal to the issue price of such debt instrument." Id; see Kirschner et al., supra note 4, at 653-59.

99. See 26 C.F.R. $\$ 1.1001-1$ (a) (1995) ("Except as otherwise provided in subtitle A of the Code, the gain or loss realized from the conversion of property into cash, or from the exchange of property for other property differing materially either in kind or in extent, is treated as income or as loss sustained.").

100. See Rev. Rul. 89-122, 1989-2 C.B. 200; Rev. Rul. 81-169, 1981-1 C.B. 429.

101. See Rev. Rul. 73-160, 1973-1 C.B. 365. 


\section{The Holdout Problem and an Alternative Solution}

The primary reason the Second and Fifth Circuits rejected Judge Liffand's Chateaugay decision is that they were concerned that the bankruptcy court ruling would render out-of-court workouts ineffective. No bondholder, the appellate courts reasoned, would rationally participate in a debt-for-debt exchange offer if he knew that his bankruptcy claim would be reduced after tendering. ${ }^{102}$ The appellate courts feared that the bankruptcy court ruling had exacerbated what had come to be known as the "holdout problem."103

"Holdout problem" is the term used to describe a structural disincentive for creditors to participate in an exchange offer. Because an exchange offer leaves a debtor more able to pay residual creditors in full, there exists an incentive for creditors to "hold out" and not tender. If enough bondholders refuse to participate in an exchange offer, the workout fails and the company must enter bankruptcy, leaving all parties worse off. ${ }^{104}$

It was widely asserted that Judge Lifland's decision put an additional obstacle in front of bondholders considering participation in an exchange offer by potentially reducing their claims in bankruptcy. ${ }^{105}$ Anecdotal evidence from bankruptcy practitioners suggests that, after the Chateaugay decision, successful out-of-court workouts were indeed more difficult to achieve. ${ }^{106}$ Despite the reversal of Chateaugay, however, commentators have noted that Chapter 11 remains the most popular method of restructuring companies. ${ }^{107}$

Observers of the holdout phenomenon have postulated that it can be mitigated through the use of techniques that render tendering debtholders better off than the holdouts. ${ }^{108}$ Specifically, commentators have claimed that issuing new debt that is senior to the old debt can reduce the holdout problem, for "[i]n the event of bankruptcy, the newly-created senior debt will be entitled to payment before the old debt."109 Economists Robert Gertner and David Scharfstein have developed a mathematical model of the decision to tender in

102. Texas Commerce Bank v. Licht (In re Pengo Indus.), 962 F.2d 543, 549 (5th Cir. 1992) ("Creditors faced with the choice of either refusing to exchange or accepting the exchange offer would certainly realize that if they choose to exchange, their claim in a subsequent bankruptcy proceeding would shrink by the amount of unamortized OID."); Chateaugay, 961 F.2d at 382 ("[The Chateaugay] ruling creates a disincentive for creditors to cooperate with a troubled debtor . ...").

103. See Coffee \& Klein, supra note 9, at 1248; Gilson, supra note 5, at 67; Kirschner et al., supra note 4, at 662. See generally Mark J. Roe, The Voting Prohibition in Bond Workouts, 97 YALE L.J. 232 (1987) (describing holdout problem and techniques to mitigate it).

104. See Roe, supra note 103 , at 236.

105. See, e.g., Kirschner et al., supra note 4, at 658.

106. See, e.g., Mark A. Hershey, Note, Face Value Exchanges, Original Issue Discount, and Elimination of the "LTV Risk": In Re Chateaugay Paints a Legal Landscape, 38 VILL. L. REV. 801, 817 (1993); Barbara Franklin, A Boost to Workouts, N.Y. L.J., Apr. 16, 1992, at 5.

107. See Lillian E. Kraemer \& Richard B. Paige, Consensual Workouts-Bankruptcy Alternative for the 1990s?, in 14 BANKING AND COMMERCIAL LENDING LAW 251, 255-56 (Richard T. Nassberg ed., 1994).

108. See, e.g., Coffee \& Klein, supra note 9, at 1242-51; Roe, supra note 103, at 246-50.

109. Roe, supra note 103, at 247. 
a public debt restructuring and had concluded that bondholders will not hold out if the newly issued security is senior to the old. ${ }^{110}$ Moreover, Gertner and Scharfstein postulate that the newly issued security may have a lower value than the old security and still eliminate holdouts, so long as the security is senior. ${ }^{11}$

A common method of facilitating exchange offers in which the new debt is senior to the old debt is the use of exit consent provisions, which have become an increasingly popular tool to discourage creditors from holding out. In many exchange offers, companies have attempted to amend the indenture under which the old securities had been issued, either to strip the outstanding bonds of protective covenants or to subordinate them to the new securities. ${ }^{112}$ Debtors could accomplish this by requiring bondholders to vote to amend the old securities before they could tender. Delaware courts have upheld the legality of these exit consent provisions. ${ }^{113}$ In addition, the SEC has consistently held that such modifications governing payment priority or subordination do not result in the offer or sale of a new security under the Securities Act, enabling such exchange offers to proceed without the registration burdens associated with the issuance of a new security. ${ }^{114}$

Economists have argued that bankruptcy courts should enforce the strict priority of claims. They note that, to the extent that priority violations and their attendant losses are anticipated by potential lenders, the cost of capital is increased. ${ }^{115}$ Legal scholars concur, noting that subordination agreements should not be jeopardized in bankruptcy, the time when senior creditors depend on such agreements. Clearly, subordination agreements are only meaningful when a corporation becomes insolvent. ${ }^{116}$ These agreements are an important tool to enable debt-laden companies to borrow funds, and there is a broad consensus that the full enforcement of subordination agreements fosters an efficient raising of capital. ${ }^{117}$

110. See Robert Gertner \& David Scharfstein, A Theory of Workouts and the Effects of Reorganization Law, 46 J. FiN. 1189, 1202-03 (1991).

111. Id.

112. Coffee \& Klein, supra note 9, at 1211-12. This technique was successfully used in both the Chateaugay and Pengo cases. See Chateaugay, 961 F.2d at 380; Pengo, 962 F.2d at 545 ("The Old Debentures were subordinated to payment in full of the New Debentures.").

113. See Katz v. Oak Indus., Inc. 508 A.2d 873 (Del. Ch. 1986); Kass v. Eastern Air Lines, No. 8700, 1986 WL 13008 (Del. Ch. Nov. 14, 1986).

114. See Bryant B. Edwards \& Jon J. Bancone, Modifying Debt Securities: The Search for the Elusive "New Security" Doctrine, 47 Bus. LAw. 571, 601 (1992).

115. See, e.g., Weiss, supra note 40 , at 71 .

116. See, e.g., Daniel C. Cohn, Subordinated Claims: Their Classification and Voting Under Chapter II of the Bankruptcy Code, 56 AM. BANKR. L.J. 293, 296 (1982) ("A subordination agreement would be nearly useless if not enforceable in a bankruptcy case.").

117. See, e.g., In re Credit Indus. Corp., 366 F.2d 402, 410 (2d Cir. 1966). The Second Circuit held that failing to enforce subordination agreements in bankruptcy "would not only place in jeopardy literally billions of dollars of outstanding loans, but in all probability would prompt lending institutions to reconsider, and possibly curtail, their subordinated debt-financing activities to the detriment of the entire business community." Id. 
As a practical matter, however, subordination agreements generally are not fully enforced in bankruptcy. ${ }^{118}$ In bankruptcy, a debtor may propose a plan for confirmation in which both senior and subordinated creditors receive partial payment on their claims. ${ }^{119}$ In addition, the Code provides that each impaired class of claims must approve the plan by two-thirds in amount and a majority in number for consensual confirmation. ${ }^{120}$ If a subordinated class or other impaired class of creditors contests confirmation of a plan, that plan can be confirmed only with the use of a "cramdown," 21 which often entails costly litigation and delays. ${ }^{122}$ The threat of forcing a cramdown is the key to subordinated debt's "nuisance value," which enables subordinated debt to extract value that the subordination agreement does not allow. ${ }^{123}$

Because any impaired class can force a cramdown, senior debt with OID generated during an exchange offer has the power to force a cramdown if its senior claim is not satisfied in full. Therefore, holders of senior debt are equipped with the bargaining leverage in bankruptcy to ensure that they receive greater satisfaction of their claims than do holdouts who possess the subordinated debt. Junior creditors, on the other hand, cannot credibly use the threat of forcing a cramdown to extract a payout greater than the payout for the senior creditors. This is because, under a cramdown, a plan for confirmation must satisfy the "fair and equitable standard" such that a

118. A recent study showed that strict priority was violated in almost $80 \%$ of consensual workouts such that junior bondholders were paid a percentage of their claims even though senior creditors were not paid in full. See Weiss, supra note 40 , at 75-76. Recent bankruptcy court decisions, consistent with the views of most scholars, have shown a willingness to enforce subordination agreements in bankruptcy. See, e.g., In re Holly's, Inc., 140 B.R. 643 (Bankr. W.D. Mich. 1992). The Holly's court noted that "there is no settled black letter law regarding subordination agreements" and that there is "a relative lack of reported bankruptcy cases which discuss subordination agreement issues in depth." Id. at 667. After reviewing commentary and case law on the subject, the Holly's court concluded that "§ 510(a) of the Bankruptcy Code and U.C.C. \$ 1-209 . . expressly permit[] enforceability of subordination agreements under applicable state law." Id. at 679; see also In re Chicago, S. Shore \& S. Bend R.R., 146 B.R. 421, 426 (Bankr. N.D. Ill. 1992) ("This agreement is typical of subordination agreements generally enforced .... The terms are clear and the intent of the parties unequivocal. PB\&T [junior creditor] is not to receive payments from the Debtor until the [senior] Lenders are paid in full."). In November 1993, a bankruptcy court ruling endorsed the literal interpretation of subordination agreements. See In re Envirodyne Indus., 161 B.R. 440 (Bankr. N.D. Ill. 1993), aff'd, 29 F.3d 301 (7th Cir. 1994). The court held that in the context of a reorganization, holders of subordinated debt could not receive any payment until senior creditors were paid in full, stating:

The very purpose of subordination clauses is to allow holders of senior indebtedness to recover if the debtor cannot meet its obligations. In other words, in the case of a bankruptcy or a reorganization, the senior debt holders bargained to insure that they would recover on their Id. at 448. claim before any junior debt holder could recover on their claim.

119. 11 U.S.C. $\$ 1123$ (1994) governs the contents of a reorganization plan.

120. See id. $\$ \S 1126$ (c), 1129(a).

121. Id. $\S 1129(\mathrm{~b})$. When a plan can be confirmed only over the dissent of a class of creditors, a special procedure known as a "cramdown" applies to protect dissenting classes. See Kenneth N. Klee, All You Ever Wanted to Know About Cram Down Under the New Bankruptcy Code, 53 AM. BANKR. L.J. 133, 134 (1979). The term "cramdown" refers to the fact that the dissenters' claims are adjusted downward without their consent.

122. See Kraemer \& Paige, supra note 107 , at 301.

123. Id. at 300-01. 
dissenting senior class of creditors must be provided for in full before any junior class can retain any property. ${ }^{124}$ Thus, the nuisance value of subordinated debt can extract some value from the senior creditors but not enough to significantly compromise full payment of the senior debt. The senior status of exchange offer participants grants them the power to hold up the plan confirmation in bankruptcy unless their claims are satisfied to their satisfaction vis-à-vis the junior creditors.

The holdout problem could be averted through the use of subordination agreements in exchange offers. Furthermore, the problem would not be exacerbated by the bankruptcy court's Chateaugay decision, which reduces the claims of tendering bondholders if creditors could expect that in bankruptcy they would be paid a greater amount than bondholders who hold out. That is, full or nearly full payment of a smaller claim would likely be preferred by risk-averse creditors over an uncertain payment of a somewhat larger subordinated claim, because in bankruptcy the most probable scenario would be a greater recovery for the senior creditors.

A creditor will participate in an exchange offer only if it is the best strategy to recover on his investment. It is true, as critics of the Chateaugay decision allege, that a claim reduction in bankruptcy may be a disincentive to participation in an exchange offer in which the new debt has the same payment priority as the old debt. Creditors would be more likely to participate if there were no claim reduction than they would be if there were one. If the old debt is subordinated to the newly issued debt, however, the nominal-value bankruptcy claim associated with the senior debt is a less significant factor in the creditor's decision to tender than is payment subordination. The payment priority of senior debt would induce creditor participation in an exchange offer whether or not the senior debt's bankruptcy claim is marked to market, as in Chateaugay, or is preserved at face value. Where there is an exchange offer in which the new debt is contractually senior to the old, the Chateaugay markto-market rule should not affect a creditor's strategic choice in most conceivable irstances.

At the time of a troubled debt restructuring, the old debt is trading at less than face value because the expected value of the claim is less than the face amount. That is, the market price incorporates the possibility that the claim

124. 11 U.S.C. $\$ 1129$ (b)(2) provides:

For the purpose of this subsection, the condition that a plan be fair and equitable with respect to a class includes the following requirements:

(B) With respect to a class of unsecured claims-

(i) the plan provides that each holder of a claim of such class receive or retain on account of such claim property of a value, as of the effective date of the plan, equal to the allowed amount of such claim; or

(ii) the holder of any claim or interest that is junior to the claims of such class will not receive or retain under the plan on account of such junior claim or interest any property. 
will not be paid in full. If a new security is issued that is senior to the old, with the claim fixed at that market value, a tendering creditor has a senior claim for the amount the market expects a holder of the old obligation to receive. A tendering creditor would be worse off than a holdout in two scenarios: (1) the restructuring is a complete success and creditors are paid in full; (2) holdouts are paid a larger percentage of their claims in bankruptcy than the market expected before the exchange.

In the first scenario, an avoidance of bankruptcy altogether, which drives the holdout phenomenon in general, it is irrelevant whether bankruptcy claims for tendering bondholders are valued at face or market value because the company never enters bankruptcy. Thus, the Chateaugay mark-to-market rule would not make tendering creditors any worse off than they would be with no OID recognition. For example, assume Company $A$ completed a face-value debt-for-debt exchange such that its $\$ 1000$-face-amount obligations, trading at $\$ 700$, are exchanged for new senior $\$ 1000$-face-amount obligations with a maturity extension. Under the Lifland decision, the tendering creditors would have a bankruptcy claim of $\$ 700$ and the holdouts would have a bankruptcy claim of $\$ 1000$; under the Second Circuit decision, both the tendering creditors and the holdouts would have a bankruptcy claim of $\$ 1000$. However, if Company $A$ is able to avoid bankruptcy, the reduction in claims of the tendering creditors would not make them any worse off than under the Second Circuit rule, because the tendering creditors would be paid in full if the company avoids bankruptcy. Tendering creditors would be worse off than holdouts if the company avoids bankruptcy because only tendering creditors accepted the maturity extension.

The second scenario, a lesser payout to tendering creditors caused by marking claims to market, is highly unlikely because the market valuation at the time of the exchange incorporates the possibility that bankruptcy may be avoided. With bankruptcy certain, the expected payout to creditors is in all likelihood going to be less. Even with a tendering creditor's claim marked to market, first-in-line satisfaction of this claim has a higher expected payout than the likely payout on the old obligation with bankruptcy certain. For example, assume Company $A$ completes a face-value debt-for-debt exchange such that its $\$ 1000$-face-amount obligations, trading at $\$ 700$, are exchanged for new senior $\$ 1000$-face-amount obligations with a maturity extension. Under the Lifland decision, the tendering creditors would have a bankruptcy claim of $\$ 700$ and the holdouts would have a bankruptcy claim of $\$ 1000$; under the Second Circuit decision, both the tendering creditors and the holdouts would have a bankruptcy claim of $\$ 1000$. In this scenario, the Lifland rule favors holdouts over tendering creditors more than does the Second Circuit rule only if the company enters bankruptcy and has enough value in the estate to pay the senior creditors $\$ 700$ and the holdouts more than $\$ 700$. This would be a highly unusual event, because the old obligations should not have been trading at 
$\$ 700$ if in bankruptcy the estate has enough value to pay out more than $\$ 700$ per obligation. Generally, the price at which a debt instrument traded prior to bankruptcy will exceed the payout on the instrument if the company enters bankruptcy.

Thus, it would be a rare instance when the Chateaugay mark-to-market regime would be the deciding factor for a creditor making the decision to tender for senior securities. Creditors who weigh the risks and rewards of participation in an exchange offer would, in most instances, agree to tender and have their bankruptcy claims reduced as long as the new debt was senior to the old. Therefore, if there is an exchange offer in which the old debentures, through an exit consent provision, are subordinated to the new debentures, bondholders who tender would likely be in a better position than holdouts in the event of bankruptcy. The holdout problem should not be severe, even if $\mathrm{OID}$ is generated during the exchange. As long as old debt is exchanged for contractually senior debt, creditor participation in exchange offers would not be impeded by Judge Lifland's Chateaugay decision.

\section{CONCLUSION}

Judge Lifland's Chateaugay decision was improperly overruled. The critics who urged its reversal and the courts of appeals have failed to assess accurately the underlying economic substance of a debt-exchange transaction and have created a legal rule that is unworkable. It is likely that companies will exploit the courts' mistaken emphasis on the face value of a bond by issuing new debt with enough original issue discount such that the transaction can be characterized as a "face value" exchange. Instead of marking claims to market only when the principal amount of the indebtedness has been reduced, bankruptcy claims should be determined by the market value surrendered to the debtor in exchange for the new obligation. The sole justification for reversing the bankruptcy court decision was to promote out-of-court workouts. The use of senior debt in the context of an exchange offer, however, can advance the efficiency goals of the courts of appeals without a reversal of Chateaugay. 